\title{
Reconstructing Holocene land-use change and sediment budgets in the Rhine system
}

\author{
Peter Houben ${ }^{1}$, P. Burgeraaff ${ }^{2}$, T. Hoffmann² ${ }^{2}$ K. Kleefeld² ${ }^{2}$ A. Zimmermann ${ }^{3}$ and R. Dikau ${ }^{2}$ \\ ${ }^{1}$ Department of Physical Geography, Goethe-University Frankfurt/M., Germany; houben@em.uni-frankfurt.de \\ ${ }^{2}$ Department of Geography, University of Bonn, Germany \\ ${ }^{3}$ Institute of Prehistoric Archaeology, University of Cologne, Germany
}

The RhineLUCIFS project is part of the LUCIFS activity (Land Use and Climate Interactions with Fluvial Systems) of PAGES Focus 4. RhineLUCIFS is concerned with human-environment interactions in the Rhine catchment $\left(185,000 \mathrm{~km}^{2}\right)$ during the period of agriculture, and includes research groups from archeology, geomorphology and historical geography. Sediment budget approaches represent the central analytical framework for understanding the complex forcing-response relationships in the Rhine system. In order to quantitatively link sediment transfer along the sediment cascade with human activities, new methods of quantifying human impact have been sought. A further key element has been the development of spatio-temporal scaling methodologies through the regionalization of local casestudies of human and climatic drivers.

The general objectives (cf. Dikau et al., 2005) of the subprojects are:

- Regionalization and quantification of htorical land use and settlement data for the last 1,000 years.

- Estimation of past population density and land use demand between the 6th millennium $B C$ and the 7th century $A D$ from archeological and palynological data.

- Modeling of Holocene human-impacted sediment budgets and fluxes at different spatial and temporal scales.

The research area of the historical geography study is located in the northern German part of the Lower Rhine Embayment close to the Dutch-German border. For a number of areas in the Lower Rhine Embayment, detailed land survey maps showing land use and dated bank migration are available for the period since 1740 AD. Figure 1 depicts an example of a modern re-mapping of land use patterns around $1730 \mathrm{AD}$, which allows calculation of agricultural area, productivity and changes in potential flooding areas. These data make it clear that the river Rhine has played a more important role in shaping and changing the landscape than previously assumed: settled areas were significantly impacted by river meander migration and flooding. Further steps of this project include regionalized reconstructions of land use changes in the period between 1150 AD and 1740 AD based on documentary archives (Burggraaff and Bub, 2005).

The archeological research project is based on scaling population densities during different archeological periods. At the scale of "single sites" (typically sized from $1,000 \mathrm{~m}^{2}$ to $10,000 \mathrm{~m}^{2}$ ) the number of graves or households is quantified and nor- malized by its time interval (generations). At the scale of "key areas" (10 to $100 \mathrm{~km}^{2}$ ) the maximum area utilized by a person or household can be calculated, provided that all sites are more-or-less known. Such systematic data sets are available for the open-cast mining region (Aldenhovener Platte) between Cologne and Aachen. At the "small-scale" level of archeological distribution maps (1:500,000 to 1:2,500,000), isolines are constructed which circum-

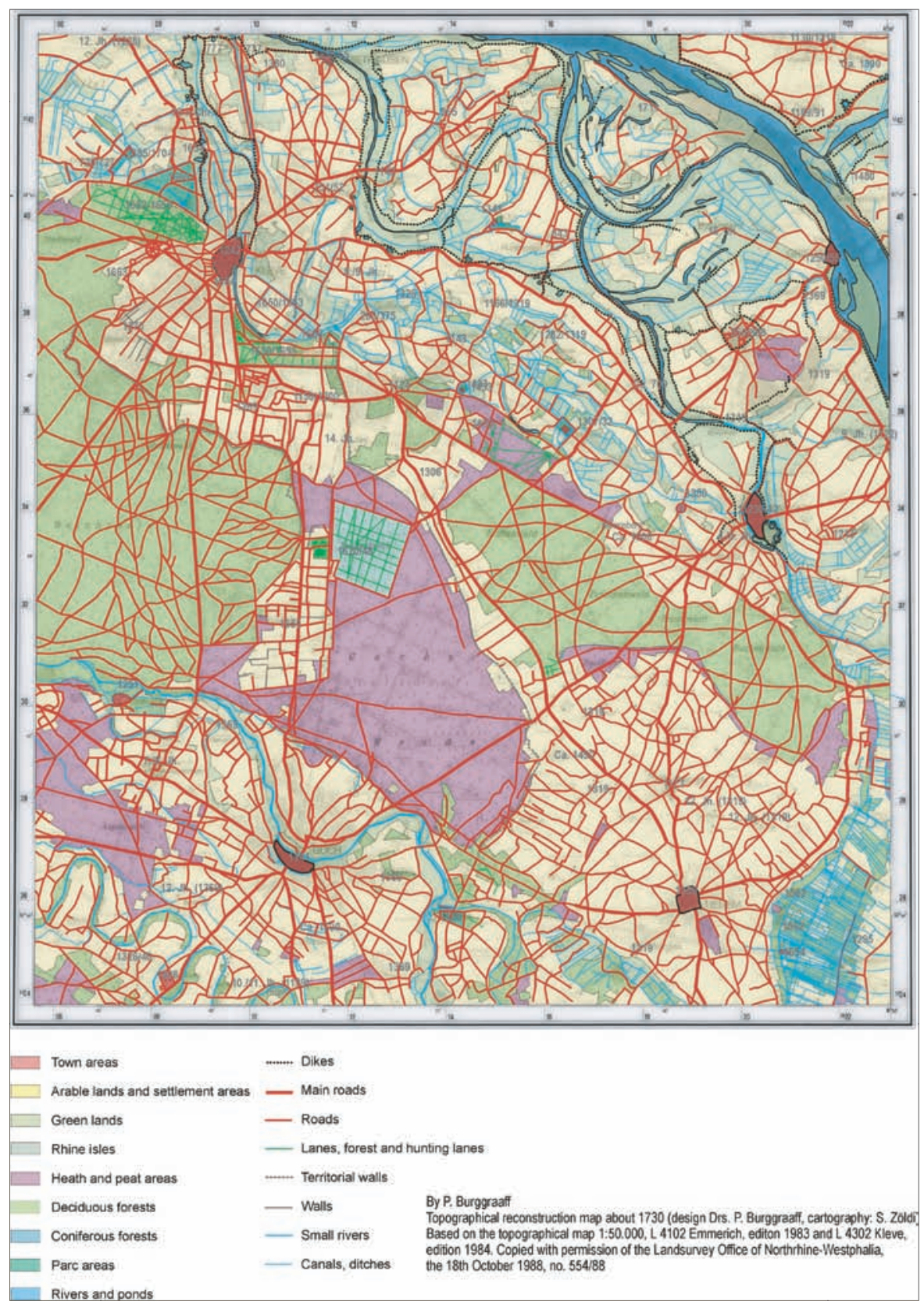

Figure 1: Land use map some time around $1730 \mathrm{AD}$ of a region in the Lower Rhine embankment reconstructed from archives by historical geography (Burggraaff \& Bub, 2005). 
scribe settlement areas with high site densities (Fig. 2) using a geometrical construction of the largest empty circles between sites. Circle radii are used to interpolate site density by the geostatistical technique of kriging. Finally, a statistical criterion (derivation of "maximum increase of enclosed space" between isolines) defines a threshold-value that identifies the border of the settlement areas (Zimmermann et al., 2004).

Quantitative sediment budget approaches allow the integration of soil erosion and in-system sedimentation within a systems framework. The Frankfurt working group concentrates on testing the suitability of spatially distributed soil survey data scaled at 1:50,000 to produce Holocene sediment budgets at scales from 10 to $2,000 \mathrm{~km}^{2}$ (Houben at al., 2006). A data modeling approach utilizing database and Geographical Information System (GIS) applications was developed to derive overall Holocene sediment budgets for 93 small sub-catchments and the larger Nidda catchment $\left(1,942 \mathrm{~km}^{2}\right)$. The results of data modeling are validated by comparison to the results of an empirical sediment budget study, which is based on independent field-based data. The detailed empirical sediment budget provides a wealth of additional information on human-induced sediment fluxes. Based on an extensive field-derived dataset $(>700$ corings, several soil pits, Optical Stimulationed Luminescence and radiocarbon dating), the GIS database delivers a spatially distributed sediment budget for the last $7.5 \mathrm{kyr}$, with estimates of flux between budget elements (Fig. 3) and information on the time-dependent change in rates of catchment delivery. Error estimation and tests of data consistency show the data to be reliable. On-slope and valley floor fluxes show significant differences in erosion, storage and delivery because of a differential behavior along the sediment cascade. Nearly $71 \%$ of all sediments produced are still resting in the catchment (Sediment Delivery Ratio $(S D R)=29 \%)$. The largest portion of sediments is stored as colluvium on slopes (83\% of stored sediments). For the past 7,500 years the catchment sediment production rate $(1.3 \mathrm{t} / \mathrm{ha} / \mathrm{yr}, 89$ $\mathrm{mm} / \mathrm{kyr}$ ) exceeds the net erosion rate (0.4 t/ha, $26 \mathrm{~mm} / \mathrm{kyr}$ ), which causes a significant accumulation of slope-derived sediments. The budget values also illustrate the virtual velocity of slope-derived sediments through the catchment. The overall catchment-scale flux of human-induced sediments is considerably slow, with a mean residence times of slope colluvium and alluvium estimated at $11.9 \mathrm{kyr}$ and 2.3

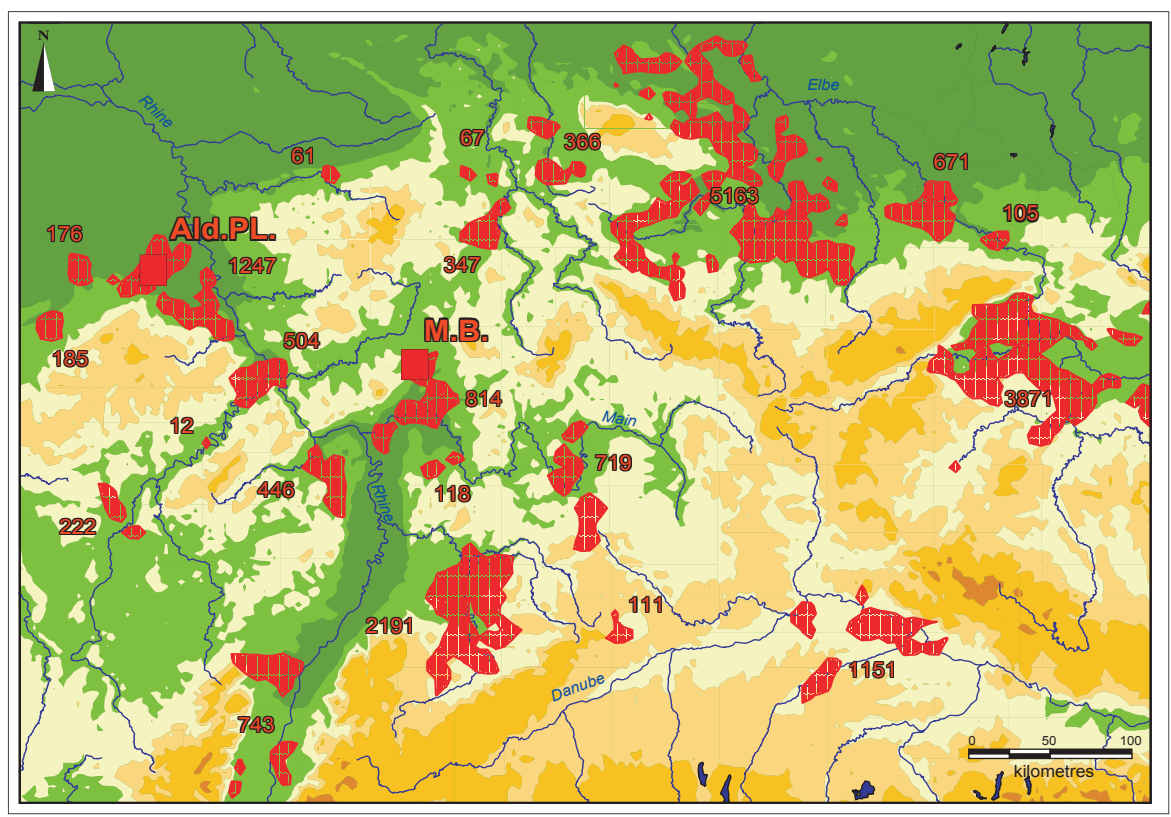

Figure 2: Early Neolithic settlement areas of Central Europe ( 5,000 BC) based on the $4 \mathrm{~km}$ isoline. The numbers reflect the quantity of households derived by the size of settlement areas and corrected by a regression function. For upscaling data of the key areas Aldenhovener Platte (Ald.PI.) and Mörlener Bucht (M.B.) were used (Zimmermann et al., 2004) (GAR= maps of the "Geschichtlicher Atlas der Rheinlande" at 1:500,000 scale).

kyr respectively. OSL and ${ }^{14} \mathrm{C}$ dating show that human-induced sediment production began in the Neolithic and has continued to the present. However, there are strong indications that delivery from the small Rockenberg catchment was decoupled from the downstream drainage network until the Early Medieval period. After the Early Medieval there was a temporary, but significant, rise in rates of sediment delivery to the downstream floodplain.

On a regional scale the sediment budget modeling approach of RhineLUCIFS is related to the entire Rhine system. Alluvial sediment storage in the Rhine catchment has been quantified from synoptic analysis of both local field studies of fluvial sediment deposition and geological maps (see Fig. 1c in Hoffmann et al., this Newsletter). The total mass of alluvial sediment deposited in the Rhine system during the Holocene is calculated at $58.9 \pm 13.7 \times 109 \mathrm{t}$, corresponding to a mean erosion rate of

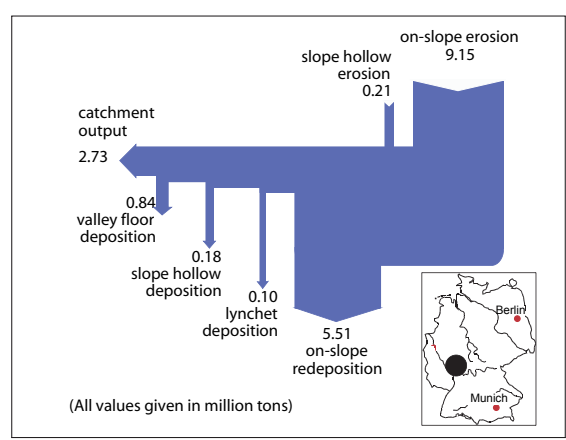

Figure 3: Holocene sediment budget for the small Rockenberg catchment north of Frankfurt (Germany). Long-term sediment storage is represented by on-slope redeposition (59\% of all mobilized sediments). Valley floor alluvium accounts for $9 \%$, while the catchment output equals 29\% of all the sediment produced (Houben, in prep.).
$0.55 \pm 0.14 \mathrm{t} / \mathrm{ha} / \mathrm{yr}(38.9 \pm 10.8 \mathrm{~mm} / \mathrm{kyr})$, averaged over the last $10 \mathrm{kyr}$ BP. This value is low compared to other calculations of long term erosion rates across Central Europe because (1) the method excludes soil erosion related deposition on hillslopes, and (2) linear Holocene averages mask changing rates of erosion and accumulating floodplain sediments since the mid-Holocene. The PAGES-LUCIFS program gave the impetus to strengthen research efforts to explore the river Rhine's responses to climate change and human activities, and the program has led to several methodological developments for studying very large catchments. Ongoing activities include a systems-based integration of paleoclimate data and biogeochemical fluxes of carbon, nitrogen and phosphorus.

\section{References}

Burggraaff, P. and Bub, G., 2005: Das Modellgebiet Unterer Niederrhein im DFG-Projekt RheinLUCIFS, Siedlungsforschung - Archäologie - Geschichte - Geographie, 23: 343-415.

Dikau, R., Herget, J. and Hennrich, K., 2005: Land use and climate impacts on fluvial systems during the period of agriculture in the River Rhine catchment (RhineLUCIFS) - an introduction, Erdkunde, 59: 177-183.

Hoffmann, T., Erkens, G., Cohen, C., Houben, P., Seidel, S. and Dikau, R., 2007: Holocene floodplain sediment storage and hillslope erosion within the Rhine catchment, Holocene, 17(1): 105-118.

Houben, P., in prep: A sediment budget for Rockenberg catchment after 7500 years of arable cultivation, Wetterau loess basin, Germany.

Houben, P., Hoffmann, T., Zimmermann, A. and Dikau, R., 2006: Land use and climatic impacts on the Rhine system during the period of agriculture (RheinLUCIFS): Quantifying sediment fluxes and human impact with available data, Catena, 66: 42-52.

Zimmermann, A., Richter, J., Frank, T. and Wendt, K. P. (2004): Landschaftsarchäologie II. Überlegungen zu Prinzipien einer Landschaftsarchäologie.- Berichte der Römisch-Germanischen Kommission, 85: 37-95. 